\title{
Recombinant bone morphogenetic protein-2 and platelet-derived growth factor-BB for localized bone regeneration. Histologic and radiographic outcomes of a rabbit study
}

Thoma, Daniel S ; Lim, Hyun-Chang ; Sapata, Vitor M ; Yoon, Sora R ; Jung, Ronald E ; Jung, Ui-Won

\begin{abstract}
OBJECTIVES: Improvement in localized bone regeneration is needed to avoid the use of autogenous tissue. For that purpose, the use biologic mediators was proposed. The aim was to test whether or not one of two biologic mediators, recombinant human bone morphogenetic protein-2 (rhBMP-2) or recombinant plateletderived growth factor (rhPDGF-BB), is superior to the other and to control groups for localized bone regeneration. MATERIALS AND METHODS: Four cylinders (height: $5 \mathrm{~mm}$; diameter: $7 \mathrm{~mm}$ ) were screwed on the parietal and frontal bones at the cranium in 12 rabbits. The cylinders either received (i) deproteinized bovine bone mineral (DBBM) mixed rhBMP-2 (DBBM/BMP-2), (ii) DBBM mixed with rhPDGF-BB (DBBM/PDGF), (iii) DBBM (DBBM), and (iv) empty control (control). Rabbits were euthanized at 2 and 8 weeks ( $n=6$, respectively). Conventional histomorphometric and micro-CT analyses were performed. Parametric linear mixed models were applied for the analyses with Bonferroni correction for the multiple group comparisons. RESULTS: The area of bone regeneration (histology; AAHisto ) at 2 weeks peaked for DBBM (41.91\%) with statistically significantly greater values compared to DBBM/PDGF and the control group $(\mathrm{P}<0.05)$. At 8 weeks, mean AAHisto values were $96.29 \%$ (DBBM/BMP-2), 46.37\% (DBBM/PDFG), 39.66\% (DBBM), and 35.98\% (control) (DBBM/BMP-2 vs. all groups (P $<0.05)$ ). At 8 weeks, bone regeneration was greatest for DBBM/BMP-2 (35.62\%) with statistically significant differences compared to all other groups $(\mathrm{P}<0.05)$. The area of bone regeneration (micro-CT; AAm-CT $)$ at 2 weeks amounted to $43.87 \%$ (DBBM/BMP-2), 42.81\% (DBBM/PDFG), 48.71\% (DBBM), and 0.96\% (control). The control group demonstrated statistically significantly less AAm-CT compared to all groups $(\mathrm{P}<0.05)$. At 8 weeks, mean AAm-CT values were 63.65\% (DBBM/BMP-2), 50.21\% (DBBM/PDFG), 44.81\% (DBBM), and 4.57\% (control) $(\mathrm{P}>0.05)$. CONCLUSIONS: The use of rhBMP-2 significantly enhanced bone regeneration compared to all other groups including the group with rhPDGF-BB.
\end{abstract}

DOI: https://doi.org/10.1111/clr.13002

Posted at the Zurich Open Repository and Archive, University of Zurich

ZORA URL: https://doi.org/10.5167/uzh-136337

Journal Article

Accepted Version

Originally published at:

Thoma, Daniel S; Lim, Hyun-Chang; Sapata, Vitor M; Yoon, Sora R; Jung, Ronald E; Jung, Ui-Won (2017). Recombinant bone morphogenetic protein-2 and platelet-derived growth factor-BB for localized bone regeneration. Histologic and radiographic outcomes of a rabbit study. Clinical Oral Implants Research, 28(11):e236-e243.

DOI: https://doi.org/10.1111/clr.13002 
Recombinant bone morphogenetic protein-2 and platelet-derived growth factor-BB for localized bone regeneration. Histologic and radiographic outcomes of a rabbit study

Thoma $\mathrm{DS}^{1}$, Lim $\mathrm{HC}^{2}$, Sapata $\mathrm{VM}^{1}$, Yoon $\mathrm{SR}^{3}$, Jung $\mathrm{RE}^{1}$, Jung $\mathrm{UW}^{3}$

${ }^{1}$ Clinic for Fixed and Removable Prosthodontics and Dental Material Science, University of Zurich, Zurich, Switzerland

${ }^{2}$ Department of Periodontology, School of Dentistry, Kyung Hee University, Seoul, Korea

${ }^{3}$ Department of Periodontology, Yonsei University, College of Dentistry, Seoul, Korea

Key words: bone augmentation, rhPDGF-BB, rhBMP-2, platelet-derived growth factor-BB, bone morphogenetic protein-2, deproteinized bovine bone mineral.

Running title: GBR using rhPDGF-BB and rhBMP-2

Address for correspondence:

Ui-Won Jung, PhD. DDS.

Department of Periodontology, Yonsei University, College of Dentistry

50-1 Yonseiro Seodaemungu, Seoul, 120-752, South Korea

Phone: +82 2 2228-3185

Fax: +82 23920398

e-mail:

drjew@yuhs.ac 


\section{Abstract}

Objectives: Improvement in localized bone regeneration are needed in order to avoid the use of autogenous tissue. For that purpose, the use biologic mediators were proposed. The aim was to test whether or not one of two biologic mediators, recombinant human bone morphogenetic protein-2 (rhBMP2) or recombinant platelet-derived growth factor (rhPDGF-BB), is superior to the other and to control groups for localized bone regeneration.

Materials and Methods: Four cylinders (height: $5 \mathrm{~mm}$; diameter: $7 \mathrm{~mm}$ ) were screwed on the parietal and frontal bones at the cranium in 12 rabbits. The cylinders either received (i) deproteinized bovine bone mineral (DBBM) mixed rhBMP-2 (DBBM/BMP-2), (ii) DBBM mixed with rhPDGF-BB (DBBM/PDGF), (iii) DBBM (DBBM), and (iv) empty control (control). Rabbits were euthanized at 2 and 8 weeks ( $n=6$, respectively). Conventional histomorphometric and micro CT analyses were performed. Parametric linear mixed models were applied for the analyses with Bonferroni correction for the multiple group comparisons.

Results: The area of bone regeneration (histology; $A A_{H i s t o}$ ) at 2 weeks peaked for DBBM (41.91\%) with statistically significantly greater values compared to DBBM/PDGF and the control group $(p<0.05)$. At 8 weeks, mean $A A_{\text {Histo }}$ values were $96.29 \%$ (DBBM/BMP-2), 46.37\% (DBBM/PDFG), 39.66\% (DBBM) and $35.98 \%$ (control) (DBBM/BMP-2 versus all groups $(p<0.05))$. At 8 weeks, bone regeneration was greatest for DBBM/BMP-2 (35.62\%) with statistically significant differences compared to all other groups $(p<0.05)$. The area of bone 
regeneration (micro CT; $A A_{m-C T}$ ) at 2 weeks amounted to $43.87 \%$ (DBBM/BMP2), $42.81 \%$ (DBBM/PDFG), $48.71 \%$ (DBBM) and $0.96 \%$ (control). The control group demonstrated statistically significantly less $A A_{m-C T}$ compared to all groups $(p<0.05)$. At 8 weeks, mean $A A_{m-C T}$ values were $63.65 \%$ (DBBM/BMP-2), $50.21 \%$ (DBBM/PDFG), 44.81\% (DBBM) and 4.57\% (control) ( $p>0.05)$.

Conclusions: The use of rhBMP-2 significantly enhanced bone regeneration compared to all other groups including the group with rhPDGF-BB. 


\section{Introduction}

Various techniques have shown to be successful in augmenting the alveolar ridge prior to implant placement. The most commonly used techniques are the use of autogenous block grafts (Misch et al. 1992; Raghoebar et al. 1996) and guided bone regeneration (Dahlin et al. 1988; Buser et al. 1993; Hämmerle et al. 1996). Although these techniques have proven to result in positive clinical outcomes, they are all associated with limitations and drawbacks: e.g. like exposure of barrier membranes (Machtei 2001), an increase risk for infection (Simion et al. 1994), additional surgical donor site increasing patient morbidity and chair-time (Schwartz-Arad, Levin \& Sigal 2005), considerable amount of resorption during the healing process (Donos et al. 2005) and neurosensory disturbances after the harvesting of either chin or ramus block grafts (Clavero \& Lundgren 2003).

More recently, the tissue engineering principles were used to improve bone regeneration (Gothard et al. 2014). This field has focused on the investigation of bioactive molecules to induce local bone formation. The most promising factors for localized ridge augmentation include recombinant human bone morphogenetic protein-2 (rhBMP-2) and recombinant platelet-derived growth factor (rhPDGF-BB) (Jung, Thoma \& Hämmerle 2008; Fisher et al. 2013; Khojasteh et al. 2013). Whereas rh-BMP-2 induces differentiation of osteoblasts precursors cells into more mature osteoblasts-like cells (Yamaguchi et al. 1991), rhPDGF-BB has a mitogenic function, increasing the quantity of cells. 
Pre-clinical models for GBR procedures have been thoroughly evaluated in several studies as 'proof-of-principle' (Donos, Dereka \& Mardas 2015). This included DBBM (Stavropoulos et al. 2001), osteoinductive grafts (Mardas et al. 2003b c a) and biological mediators (rhBMP-2 and rhPDGF-BB) (Zellin \& Linde 1999; Cochran et al. 2000; Jung et al. 2003; Simion et al. 2006; Hasegawa et al. 2008; Thoma et al. 2010; Darby \& Morris 2013). However, there is a lack of data regarding the comparison between the two biologic mediators and compared to DBBM alone for localized bone regeneration in the same experimental model.

The aim of the present study was therefore to test whether or not one of the two biologic mediators (rhBMP-2 or rhPDGF-BB) is superior to the other and to control groups for localized bone regeneration based histological and microcomputed tomography (micro-CT) outcome measures.

The hypotheses of the present study were that the use of biologic mediators is more favorable compared to DBBM alone for localized GBR procedures and that rhBMP-2 and rhPDGF-BB differ in terms of the regenerated area based on histological and micro-computed tomography (micro-CT) outcome measures. 


\section{Materials and Methods}

Animals

The study was designed as a randomized experimental study employing 12 adults (12 months old) New Zealand white rabbits, weighing between 2.8 and $3.2 \mathrm{~kg}$ were used. The animals were kept in a purpose-designed room for experimental animals and were fed a standard laboratory diet. The study was approved by the Institutional Animal Care and Use Committee of Yonsei Medical Center, Seoul, Korea (approval no.:2014-0281).

Commercially available biological mediators were used. The preparation and the concentration applied was similar to a previous study utilizing rhBMP-2 (Jung et al. 2015).

\section{Surgical Procedure}

Anesthesia initiated by injection of $65 \mathrm{mg} / \mathrm{kg}$ of ketamine (Ketalar, Yuhan, Seoul, Korea) and 4 mg/kg of xylazine (Rompun, Bayer Korea, Seoul, Korea). The surgical procedure and the augmentation device has previously been described (Jung et al., 2007). In brief, a full thickness flap was elevated to expose the parietal and frontal bones at the cranium. Four slits $(7 \mathrm{~mm}$ in outer diameter; $1 \mathrm{~mm}$ sink depth) and perforations of the external cortical plate were prepared. Subsequently, experimental cylinders made of polycarbonate were screwed in each of the slits obtaining good stability. The dimension of the cylinders was $5 \mathrm{~mm}$ in height and $7 \mathrm{~mm}$ in outer diameter with a screw design towards the bone site and a small shoulder for a polycarbonate lid towards the 
covering skin flap.

The following 4 treatment modalities were assigned to the cylinders (Fig. 1):

(1) DBBM/BMP-2 group: rhBMP-2 (Cowellmedi, Busan, Korea) loaded DBBM (BioOss ${ }^{\circledR}$, Geistlich Biomaterials, Wolhusen, Switzerland),

(2) DBBM/PDGF group: rhPDGF-BB (GEM 21S ${ }^{\circledR}$, Osteohealth, BioMimetic Therapeutics Inc., USA) loaded DBBM,

(3) DBBM group: DBBM mixed with saline, and

(4) Control group: blood clot.

For the DBBM/BMP-2 and DBBM/PDGF groups, $0.1 \mathrm{ml}$ of rhBMP-2 (Cowellmedi, Busan, Korea) or rhPDGF-BB (GEM 21S ${ }^{\circledR}$, Osteohealth, BioMimetic Therapeutics Inc., USA) at a concentration of $0.1 \mathrm{mg} / \mathrm{ml}$ was loaded onto $0.07 \mathrm{~g}$ of DBBM granules (BioOss ${ }^{\circledR}$, Geistlich Biomaterials, Wolhusen, Switzerland), respectively. Ten minutes of binding time was provided for both groups. For the DBBM group, $0.1 \mathrm{ml}$ of saline was mixed with DBBM.

In the first animal, the treatments were randomly assigned to the cylinders. In the subsequently treated animals the sequence of the treatment modalities was kept but the locations were stepwise rotated in a clockwise direction. The cylinders were left open towards the bone and closed with a lid towards the skin flap. Primary wound closure was obtained. The rabbits were sedated with barbiturates and sacrificed by an overdose of Ketamin at 2 weeks (6 rabbits) and 8 weeks (6 rabbits). The skull containing all 4 cylinders were 
removed and placed in $40 \%$ ethanol.

\section{Histological preparation}

The obtained specimens were dehydrated in a series of graded alcohol solutions and embedded in PMMA (polymethylmetacrylate; Merck AG, Darmstadt, Germany). From each specimen, a longitudinal section through the cylinder of 80 to $100 \mu \mathrm{m}$ thickness was obtained by a micro cutting and grinding technique (EXAKT ${ }^{\circledR}$ Apparatebau, Norderstedt, Germany) adapted by Donath (Donath and Breuner, 1982) and stained with Hematoxylin-eosin (H\&E).

\section{Histology and histomorphometry}

A light microscope (Keyence VHX-S90BE, Keyence Corp., Osaka, Japan) was used. Computer-assisted histomorphometric measurements were obtained using an automated image analysis system (LAS V4.3, Leica Microsystems, Wetzlar, Germany). One central section of each cylinder was used, assessing the following parameters similar to a previously published study (Jung et al., 2008b):

1) the area of bone regeneration (area of bone regeneration [\%] = pixel number of the bone area $X 100 /$ total pixel number of the cylinder) (\%; $\left.\mathrm{AA}_{\text {Histo }}\right) ;$

2) fraction of mineralized bone related to the total area (\%; $\left.B_{\text {Histo }}\right)$;

3) fraction of bone substitute related to the total area $\left(\% ; \mathrm{BS}_{\text {Histo }}\right)$;

3) fraction of mineralized tissue (mineralized bone + bone substitute material) related to the total area $\left(\% ; \mathrm{MT}_{\text {Histo }}\right)$; 
4) fraction of non-mineralized tissue related to the total area (\%; $\left.\mathrm{NMT}_{\text {Histo }}\right)$.

Radiographic analysis: micro-computed tomography (micro-CT)

One examiner, not included in the study design and execution and unaware of the treatment modalities, performed all the measurements.

Volumetric evaluations were done at the harvested specimens with Micro-CT (SkyScan1173; SKYSCAN, Kartuizersweg 3B 2550 Kontich, Belgium) before histological preperation. Digital micro radiographic images were acquired at $130 \mathrm{kVp}$ and $60 \mu \mathrm{A}$ using $1.0 \mathrm{~mm}$ aluminum filtration. Radiation was exposed at the speed of $500 \mathrm{~ms}$ on each rotation of 0.2 degrees. High resolution images were taken with pixel size: $14.91 \mu \mathrm{m}$. For image reconstruction, images having $2240 \times 2240$ pixels were taken by computer software (Nrecon, Bruker-CT, ver.1.5.1.2). A computer software was used to divide the bone trabecular pattern and marrow cavity for bony structure analysis (Ct Analyzer, Bruker-CT, ver.1.14.4.1). The following parameters were calculated within the cylinders:

1) the area of bone regeneration $\left(\% ; A A_{m-C T}\right)$;

2) fraction of mineralized bone related to the total area $\left(\% ; B_{m-C T}\right)$;

3) fraction of bone substitute related to the total area $\left(\% ; \mathrm{BS}_{\mathrm{m}-\mathrm{CT}}\right)$;

3) fraction of mineralized tissue related to the total area $\left(\% ; \mathrm{MT}_{\mathrm{m}-\mathrm{CT}}\right)$;

4) fraction of non-mineralized tissue related to the total area $\left(\% ; \mathrm{NMT}_{\mathrm{m}}\right.$ CT).

Statistical Analysis 
The metric variables were described with mean, median, standard deviation, and quartiles. The statistical comparisons of the group mean for the metric variables applied parametric mixed linear models since the data within a rabbit were dependent (clustered). The rabbit was used as random effect in these models. The assumptions of these models were validated qualitatively in view of the small sample sizes. The tests for group mean comparisons were Bonferroni corrected. The significance level was set at $5 \%$. No correction for the multiple testing of the many parameters was applied also in view of the small sample size. 


\section{Results}

The animals did not present weight reduction or signs of local complications during the study period.

Descriptive histology

In all groups with DBBM particles, new bone formation and the bone-tobone substitute contact increased from 2 to 8 weeks. Outside of the cylinders, in some sites at 2 weeks, and in most sites at 8 weeks, massive new bone formation was evident located on top of the native bone (B) (Fig. 2-3).

At 2 weeks, in the DBBM/BMP-2 group, few trabecular bone was located close to the native bone (B), whereas the rest of the cylinder was packed with DBBM particles (BS) (Fig. 2a). At 8 weeks, bone formation filled the entire space between the DBBM particles, reaching every corner of the cylinders. The cylinders were, therefore, densely packed with mineralized tissues (Fig. 3a).

Bone formation at DBBM/PDGF sites reached a level up to half of the cylinder at 2 weeks (Fig. 2b). At 8 weeks, bone regeneration partially reached the top of the cylinder, whereas the amount of DBBM particles appeared to be reduced (Fig. 3b).

In the DBBM group, bone formation reached a level of roughly one third of the cylinder after 2 weeks (Fig. 2c). At 8 weeks, bone formation increased with bone reaching the top of the cylinders (Fig. 3c).

In the control group, bone regeneration was limited to a few trabecular on 
top of the native bone at 2 weeks (Fig. 2d). Large parts of the cylinders were filled with non-mineralized tissue. Bone formation increased, mostly along the lateral walls of the cylinder after 8 weeks, but not further coronal than half of the cylinder (Fig. 3d).

Histomorphometrical analysis

All data are presented in table 1.

The mean $\mathrm{AA}_{\text {Histo }}$ values at 2 weeks peaked for DBBM $(41.91 \% \pm 23.38 \%)$ with no statistically significant differences between the groups. At 8 weeks, mean $\mathrm{AA}_{\text {Histo }}$ values were $96.29 \% \pm 2.44 \%$ for DBBM/BMP-2, $46.37 \% \pm 26.45 \%$ for DBBM/PDFG, $39.66 \% \pm 15.06 \%$ for DBBM and $35.98 \% \pm 12.48 \%$ for control with DBBM/BMP-2 group demonstrating statistically significantly greater $\mathrm{AA}_{\text {Histo }}$ compared to all groups ( $p<0.001$ vs. DBBM/PDGF, $p<0.001$ vs. DBBM and p<0.001 vs. control group) (Fig. 4).

Bone regeneration $\left(B_{H i s t o}\right)$ at 2 weeks was minimal in all groups, but then increased up to 8 weeks. At 8 weeks, bone regeneration was greatest for DBBM/BMP-2 $(35.62 \% \pm 5.06 \%)$ with statistically significant differences compared to all other groups ( $p<0.001$ vs. DBBM/PDGF, $p<0.001$ vs. DBBM and $p<0.001$ vs. control group).

The mean values for remaining bone substitute material $\left(\mathrm{BS}_{\text {Histo }}\right)$ ranged between $31.07 \% \pm 3.55 \%$ for DBBM/BMP-2 at 2 weeks and $35.78 \% \pm 2.44 \%$ for DBBM/PDGF at 8 weeks, which was not statistically significant $(p>0.05)$.

The percentage of $\mathrm{MT}_{\text {Histo }}$ at 2 weeks ranged between $6.09 \% \pm 4.13 \%$ for the control and $47.38 \% \pm 8.32 \%$ for the DBBM group, with statistically significant 
differences between the control group compared to all other groups $(p<0.001)$. At 8 weeks the values ranged between $13.37 \% \pm 3.13 \%$ for control and $68.08 \% \pm 6.36 \%$ for DBBM/BMP-2. All differences between the groups at 8 weeks were statistically significant $(p<0.001)$ except between DBBM vs. DBBM/PDGF groups $(p=0.72)$.

Radiographic analysis: micro-computed tomography (micro-CT)

All data are presented in table 2 .

The mean regenerated area $\left(\mathrm{AA}_{\mathrm{m}-\mathrm{CT}}\right)$ at 2 weeks amounted $43.87 \% \pm 5.53 \%$ for $\quad$ DBBM/BMP-2, $\quad 42.81 \% \pm 6.46 \%$ for DBBM/PDFG, $48.71 \% \pm 8.07 \%$ for DBBM and $0.96 \% \pm 0.94 \%$ for control. The control group demonstrated statistically significantly less $A A_{m-C T}$ compared to all groups $(p<0.001)$. At 8 weeks, mean $A A_{m-C T}$ values were $63.65 \% \pm 6.1 \%$ for DBBM/BMP-2, $50.21 \% \pm 4.34 \%$ for DBBM/PDFG, $44.81 \% \pm 3.75 \%$ for DBBM and $4.57 \% \pm 1.88 \%$ for control. At 8 weeks, all differences between the groups were statistically significant $(p<0.001)$ except between DBBM vs. DBBM/PDGF groups $(p=0.27)$.

Bone regeneration $\left(B_{m-C T}\right)$ was minimal in all groups and the percentage of mineralized tissue ( $\left.\mathrm{MT}_{\mathrm{m}-\mathrm{CT}}\right)$ at 2 weeks ranged between $0.84 \% \pm 0.74 \%$ for control and $45.15 \% \pm 5.46 \%$ for DBBM, with statistically significant differences between the control group compared to all other groups $(p<0.001)$. At 8 weeks all differences between the groups were significantly different $(p<0.001)$ except between DBBM/PDGF vs. DBBM groups $(p=1.00)$. 


\section{Discussion}

The present experimental study demonstrated that the use of DBBM in combination with rhBMP-2 significantly increased the area of bone regeneration $\left(A A_{H i s t o}\right)$, the fraction of mineralized bone related to the total area $\left(B_{m-C T}\right)$ and the fraction of mineralized tissue related to the total area $\left(\mathrm{MT}_{\mathrm{m}-\mathrm{CT}}\right)$. The DBBM/PDGF group demonstrated intermediate results between DBBM and DBBM/BMP-2 groups.

The descriptive histology revealed that the use of bioactive molecules to induce local bone formation was not only limited to the cylinder itself, but was also observed outside of the cylinder. In the two groups with biologic mediators, the regenerated area within the cylinders reached the top of the cylinder (DBBM/BMP-2) or two thirds of the cylinder (DBBM/PDGF) at the later timepoints. The DBBM group was similar to the two groups with biologic mediators at 2 weeks. At 8 weeks, however, bone formation was limited and similar to the empty control group. In contrast to the groups with biologic mediators, no bone formation was observed outside of the cylinders in groups DBBM and the control group.

For the amount of regenerated area $\left(\mathrm{AA}_{\text {Histo }}\right)$, the histomorphometric analysis revealed at 2 weeks a similar performance between the groups. However, at 8 weeks, the $\mathrm{AA}_{\text {Histo }}$ values for DBBM/BMP-2 were statistically significantly greater compared to the other groups, demonstrating almost 3 times more bone formation compared to the control group and more than 2 
times compared to the DBBM/PDGF group. The micro-computed tomography analysis revealed similar outcomes for the regenerated area $\left(A A_{m-C T}\right)$. The DBBM/BMP-2, DBBM/PDGF and DBBM groups at 2 weeks rendered similar performance, but at 8 weeks the groups demonstrated significant differences between each other, and the DBBM/BMP-2 group showed the greatest regenerated area. These favorable outcomes for the use of rhBMP-2 are well in line with a number of previous investigations comparing the same biologic mediator in combination with various graft materials (Zellin \& Linde 1999; Cochran et al. 2000; Jung et al. 2003; Thoma et al. 2010). In terms of rhPDGF$\mathrm{BB}$, the results were inferior to rhBMP-2 and similar to the control group without the growth factor (DBBM). In an in vitro study, the release of rhPDGF-BB when associated with DBBM+collagen resulted in enhanced proliferation of osteoblastic cells compared to the carrier alone (Stephan et al. 2000). This is supported by another in vitro study demonstrating a fast adsorption of rhPDGF$\mathrm{BB}$ to DBBM, and, in the absence of additional proteins competing for adsorption, rhPDGF-BB remained attached (Thoma et al. 2012) and active (Stephan et al. 2000). The lack of collagen with faster degradation, and therefore an early release of biologic mediators, compared to DBBM (Stephan et al. 2000) could explain the slow bone formation at 2 weeks in the present study. The osteoconductive properties of DBBM could also be noted in the present study, corroborating with previous studies that evaluated the capability of DBBM to enhance new bone formation in GBR procedures (Hämmerle et al. 1995, 1997; Stavropoulos et al. 2001). 
The fraction of mineralized bone related to the total area $\left(\mathrm{B}_{\text {Histo }}\right)$ only rendered differences at 8 weeks. The $B_{\text {Histo }}$ showed greater values for DBBM/BMP-2 with statistically significant differences compared to all other groups. In the present study, just the control group presented statistically significant differences for the $B_{m-C T}$ at 8 weeks when compared to the others groups. Overall, microCT analyses appeared to be less sensitive compared to the histologic analyses. This might be due to the threshold value that was used for the various tissues. Previous studies comparing histologic and microCT measurements demonstrated controversial data. One in vitro study showed high correlations between histomorphometric and microCT analysis (Thimm et al. 2013), whereas other stated that to obtain valid conclusions, the analysis should be used in combination (Gielkens et al. 2008).

The mean values for the fraction of bone substitute related to the total area $\left(\mathrm{BS}_{\text {Histo }}\right)$ were similar at all time-points, demonstrating that the graft remained stable over the healing period for all augmented groups. When the percentage of mineralized tissue related to the total area were analyzed in both analysis $\left(\mathrm{MT}_{\text {Histo }}\right.$ and $\left.\mathrm{MT}_{\mathrm{m}-\mathrm{CT}}\right)$, no differences were found between the augmented groups at 2 weeks. Over the course of the following 6 weeks, a large amount of mineralized tissue was formed in the DBBM/BMP-2 group, much greater compared to the other groups. The DBBM/PDGF and DBBM groups rendered only a modest mineralized tissue formation.

There is a lack of data regarding the comparison between rhBMP-2 and rhPDGF-BB for localized bone regeneration in the same experimental model. A 
study evaluating the efficacy of different concentrations of rhBMP-2 in rabbit calvaria showed a statistically significant difference in amount of newly formed tissue when compared to the control group without rhBMP-2 (Hasegawa et al. 2008). A study in rabbit mandibles utilizing rhBMP-2 and DBBM showed outcomes in line with the data presented here, with $98 \%$ of defect area filled in the rhBMP-2 group (Chen et al. 2007), compared to $96.29 \%$ in the present study. The use of rhPDGF-BB on the rabbit calvaria in association with DBBM, showed a great potential to enhance bone regeneration (Thoma et al. 2012). Previous studies evaluated the bone regeneration using rhBMP-2 or rhPDGFBB with different carriers and/or study designs, and also demonstrated positive results in terms of the regenerated area (Wikesjö et al. 2004; Miranda et al. 2005; Simion, Rocchietta \& Dellavia 2007; Jung et al. 2009; Aghaloo et al. 2010; Nevins et al. 2012; Xu et al. 2016).

Although rhBMP-2 demonstrated significantly more bone formation at 8 weeks compared to controls, it is worthwhile to point out the high costs associated with the use of biologic mediators, specifically rhBMP-2. Moreover, rhPDGF-BB is available at a much lower price (accounting for roughly a tenth of the costs for rhBMP-2 produced from eukaryotic system per dose and patient). In the present study, rhBMP-2 produced from E. coli was used, which could yield large quantities at low costs. When roughly calculated, the cost ratio for $E$. coli derived rhBMP-2 vs. rhPDGF-BB was $1: 3$ for the same dose. The data indicated that with a third of the costs compared to rhBMP-2, DBBM/PDGF group regenerated $16.91 \%$ and $28.87 \%$ more bone than DBBM and control 
groups, respectively. The difference to DBBM/BMP-2 group was $48.15 \%$, thereby leaving room for discussion on the cost-benefit ratio from a clinical point of view.

Whereas the pre-clinical model selected to run this study is well documented (Zellin \& Linde 1999; Cochran et al. 2000; Stavropoulos et al. 2001; Mardas et al. 2003b c a; Hasegawa et al. 2008; Thoma et al. 2010; Donos et al. 2015), and has a good acceptance in an ethical point of view, the translation of pre-clinical results should be analyzed with prudence, being an animal model with different physiological responses and metabolism compared to humans. Although the use of small animals, in this case rabbits, significantly differ when compared to clinical trials in humans, this type of study is commonly used as a 'proof-of-principle'. Within the limitations of this study, further preclinical and clinical investigations with different and more challenging defects are needed.

\section{Conclusions}

The biologic mediator rhBMP-2 was superior compared to rhPDGF-BB and control groups for localized bone regeneration in terms of the amount of regenerated bone and in terms of cost-effectiveness. 


\section{REFERENCES}

Aghaloo T., Cowan C.M., Zhang X., Freymiller E., Soo C., Wu B., et al. (2010) The Effect of NELL1 and Bone Morphogenetic Protein2 on Calvarial Bone Regeneration. Journal of Oral and Maxillofacial Surgery 68: 300-308.

Buser D., Dula K., Belser U.C., Hirt H.-P. \& Berthold H. (1993) Localized Ridge Augmentation Using Guided Bone Regeneration. I. Surgical Procedure in the Maxilla. International Journal of Periodontics \& Restorative Dentistry 13: 29-45.

Chen B., Lin H., Wang J., Zhao Y., Wang B., Zhao W., et al. (2007) Homogeneous osteogenesis and bone regeneration by demineralized bone matrix loading with collagen-targeting bone morphogenetic protein-2. Biomaterials 28: 1027-1035.

Clavero J. \& Lundgren S. (2003) Ramus or chin grafts for maxillary sinus inlay and local onlay augmentation: comparison of donor site morbidity and complications. Clinical implant dentistry and related research 5: 154-160.

Cochran D.L., Jones A.A., Lilly L.C., Fiorellini J.P. \& Howell H. (2000) Evaluation of recombinant human bone morphogenetic protein2 in oral applications including the use of endosseous implants: 3-year results of a pilot study in humans. Journal of Periodontology 71: 1241-1257.

Dahlin C., Linde A., Gottlow J. \& Nyman S. (1988) Healing of bone defects by guided tissue regeneration. Plastic and Reconstructive Surgery 81: 672-676.

Darby I.B. \& Morris K.H. (2013) A Systematic Review of the Use of Growth Factors in Human Periodontal Regeneration. Journal of Periodontology 84: 465-476.

Donos N., Dereka X. \& Mardas N. (2015) Experimental models for guided bone regeneration in healthy and medically compromised conditions. Periodontology 2000 68: 99-121.

Donos N., Kostopoulos L., Tonetti M. \& Karring T. (2005) Long-term stability of autogenous bone grafts following combined application with guided bone regeneration. Clinical Oral Implants Research 16: 133-139.

Fisher D.M., Min-Leong Wong J., Crowley C. \& Khan W.S. (2013) Preclinical and clinical studies on the use of growth factors for bone repair: a systematic review. Current stem cell research \& 
therapy 8: $260-268$.

Gielkens P.F.M., Schortinghuis J., de Jong J.R., Huysmans M.C.D.N.J.M., Leeuwen M.B.M. van, Raghoebar G.M., et al. (2008) A comparison of micro-CT, microradiography and histomorphometry in bone research. Archives of Oral Biology 53: $558-566$.

Gothard D., Smith E.L., Kanczler J.M., Rashidi H., Qutachi O., Henstock J., et al. (2014) Tissue engineered bone using select growth factors: a comprehensive review of animal studies and clinical translation studies in man. European Cells and Materials 28: 166-208.

Hämmerle C.H.F., Schmid J., Olah A.J. \& Lang N.P. (1996) A novel model system for the study of experimental guided bone formation in humans. Clinical Oral Implants Research 7: 38-47.

Hämmerle C.H., Olah A.J., Schmid J., Flückiger L., Gogolewski S., Winkler J.R., et al. (1997) The biological effect of natural bone mineral on bone neoformation on the rabbit skull. Clinical Oral Implants Research 8: 198-207.

Hämmerle C.H., Schmid J., Lang N.P. \& Olah A.J. (1995) Temporal dynamics of healing in rabbit cranial defects using guided bone regeneration. Journal of Oral and Maxillofacial Surgery 53: 167-174.

Hasegawa Y., Sato S., Takayama T., Murai M., Suzuki N. \& Ito K. (2008) Short-Term Effects of rhBMP-2-Enhanced Bone Augmentation Beyond the Skeletal Envelope Within a Titanium Cap in Rabbit Calvarium. Journal of Periodontology 79: 348354.

Jung R.E., Glauser R., Schärer P., Hämmerle C.H., Sailer H.F. \& Weber F.E. (2003) Effect of rhBMP-2 on guided bone regeneration in humans. Clinical oral implants research 14: 556-568.

Jung R.E., Thoma D.S. \& Hämmerle C.H.F. (2008) Assessment of the potential of growth factors for localized alveolar ridge augmentation: a systematic review. Journal of Clinical Periodontology 35: 255-281.

Jung R.E., Windisch S.I., Eggenschwiler A.M., Thoma D.S., Weber F.E. \& Hämmerle C.H.F. (2009) A randomized-controlled clinical trial evaluating clinical and radiological outcomes after 3 and 5 years of dental implants placed in bone regenerated by means of GBR techniques with or without the addition of BMP-2. Clinical Oral Implants Research 20: 660-666. 
Jung U.-W., Lee I.-K., Park J.-Y., Thoma D.S., Hämmerle C.H.F. \& Jung R.E. (2015) The efficacy of BMP-2 preloaded on bone substitute or hydrogel for bone regeneration at peri-implant defects in dogs. Clinical Oral Implants Research 26: 14561465.

Khojasteh A., Behnia H., Naghdi N., Esmaeelinejad M., Alikhassy Z. \& Stevens M. (2013) Effects of different growth factors and carriers on bone regeneration: a systematic review. Oral Surgery, Oral Medicine, Oral Pathology and Oral Radiology 116: e405-e423.

Machtei E.E. (2001) The effect of membrane exposure on the outcome of regenerative procedures in humans: a metaanalysis. Journal of Periodontology 72: 512-516.

Mardas N., Kostopoulos L., Stavropoulos A. \& Karring T. (2003a) Denaturation of demineralized bone matrix significantly reduces bone formation by guided tissue regeneration. Clinical Oral Implants Research 14: 804-811.

Mardas N., Kostopoulos L., Stavropoulos A. \& Karring T. (2003b) Evaluation of a cell-permeable barrier for guided tissue regeneration combined with demineralized bone matrix. Clinical oral implants research 14: 812-818.

Mardas N., Kostopoulos L., Stavropoulos A. \& Karring T. (2003c) Osteogenesis by guided tissue regeneration and demineralized bone matrix. Journal of Clinical Periodontology 30: 176-183.

Miranda D.A., Blumenthal N.M., Sorensen R.G., Wozney J.M. \& Wikesjö U.M. (2005) Evaluation of recombinant human bone morphogenetic protein-2 on the repair of alveolar ridge defects in baboons. Journal of periodontology 76: 210-220.

Misch C.M., Misch C.E., Resnik R.R. \& Ismail Y.H. (1992) Reconstruction of Maxillary Alveolar Defects With Mandibular Symphysis Grafts for Dental Implants: A Preliminary Procedural Report. The International Journal of Oral \& Maxillofacial Implants 7: 360-366.

Nevins M., Hezaimi K.A., Schupbach P., Karimbux N. \& Kim D.M. (2012) Vertical Ridge Augmentation Using an Equine Bone and Collagen Block Infused With Recombinant Human PlateletDerived Growth Factor-BB: A Randomized Single-Masked Histologic Study in Non-Human Primates. Journal of Periodontology 83: 878-884.

Raghoebar G.M., Betenburg R.H.K., Vissink A. \& Reintsema H. (1996) Augmentation of Localized Defects of the Anterior Maxillary 
Ridge With Autogenous Bone Before Insertion of Implants. Journal of Oral and Maxillofacial Surgery 54: 1180-1185.

Schwartz-Arad D., Levin L. \& Sigal L. (2005) Surgical Success of Intraoral Autogenous Block Onlay Bone Grafting for Alveolar Ridge Augmentation: Implant Dentistry 14: 131-138.

Simion M., Baldoni M., Rossi P. \& Zaffe D. (1994) A comparative study of the effectiveness of e-PTFE membranes with and without early exposure during the healing period. International Journal of Periodontics \& Restorative Dentistry 14: 166-180.

Simion M., Rocchietta I. \& Dellavia C. (2007) Three-Dimensional Ridge Augmentation with Xenograft and Recombinant Human Platelet-Derived Growth Factor-BB in Humans: Report of Two Cases. International Journal of Periodontics \& Restorative Dentistry 27: 109-115.

Simion M., Rocchietta I., Kim D., Nevins M. \& Fiorellini J.P. (2006) Vertical Ridge Augmentation by Means of Deproteinized Bovine Bone Block and Recombinant Human Platelet-Derived Growth Factor-BB: A Histologic Study in a Dog Model. International Journal of Periodontics \& Restorative Dentistry 26: 415-423.

Stavropoulos A., Kostopoulos L., Mardas N., Randel Nyengaard J. \& Karring T. (2001) Deproteinized bovine bone used as an adjunct to guided bone augmentation: an experimental study in the rat. Clinical implant dentistry and related research 3: 156165.

Stephan E.B., Renjen R., Lynch S.E. \& Dziak R. (2000) Plateletderived growth factor enhancement of a mineral-collagen bone substitute. Journal of Periodontology 71: 1887-1892.

Thimm B.W., Wechsler O., Bohner M., Müller R. \& Hofmann S. (2013) In Vitro Ceramic Scaffold Mineralization: Comparison Between Histological and Micro-Computed Tomographical Analysis. Annals of Biomedical Engineering 41: 2666-2675.

Thoma D.S., Jones A., Yamashita M., Edmunds R., Nevins M. \& Cochran D.L. (2010) Ridge Augmentation Using Recombinant Bone Morphogenetic Protein-2 Techniques: An Experimental Study in the Canine. Journal of Periodontology 81: 1829-1838.

Thoma D.S., Jung R.E., Hänseler P., Hämmerle C.H.F., Cochran D.L. \& Weber F.E. (2012) Impact of Recombinant Platelet-Derived Growth Factor BB on Bone Regeneration: A Study in Rabbits. International Journal of Periodontics \& Restorative Dentistry 32: 195-202.

Wikesjö U.M.E., Qahash M., Thomson R.C., Cook A.D., Rohrer M.D., 
Wozney J.M., et al. (2004) rhBMP-2 significantly enhances guided bone regeneration. Clinical Oral Implants Research 15: 194-204.

Xu L., Zhang W., Lv K., Yu W., Jiang X. \& Zhang F. (2016) PeriImplant Bone Regeneration Using rhPDGF-BB, BMSCs, and $\beta$ $\mathrm{TCP}$ in a Canine Model: rhPDGF-BB/BMSCs/ $\beta-\mathrm{TCP}$ for Immediate Peri-Implant Bone Defects Repair. Clinical Implant Dentistry and Related Research 18: 241-252.

Yamaguchi A., Katagiri T., Ikeda T., Wozney J.M., Rosen V., Wang E.A., et al. (1991) Recombinant human bone morphogenetic protein-2 stimulates osteoblastic maturation and inhibits myogenic differentiation in vitro. The Journal of cell biology 113: $681-687$.

Zellin G. \& Linde A. (1999) Bone neogenesis in domes made of expanded polytetrafluoroethylene: efficacy of rhBMP-2 to enhance the amount of achievable bone in rats. Plastic and Reconstructive Surgery 103: 1229-1237. 
Acknowledgements and conflict of interest

The support of Prof. em. Dr. Jürg Hüsler, statistician, is highly acknowledged. The authors report no conflict of interest.

\section{Source of funding}

This study was supported by the Basic Science Research Program of the National Research Foundation of Korea (NRF) funded by the Ministry of Education (No.NRF-2014R1A1A1A05002953). 


\section{Figures legends}

Figure 1. Bone site were prepared in each of the slits, providing primary stability for the PC (polycarbonate) cylinders After augmentation with the respective treatment modalities, the four cylinders were closed with a PC lid toward the covering skin-periosteal flap (a). Micro-CT 3D image of cylinders on the rabbit cranium (b). Digital micro radiographic images of an augmented cylinder (left) and an empty control cylinder (right) (c).

Figure 2. Histologic slide at 30x magnification after 2 weeks of healing (H\&E). DBBM/BMP-2 group cylinder (a), DBBM/PDGF group cylinder (b), DBBM group cylinder (c) and empty control cylinder (d). DBBM/BMP-2 = bovine-derived particulated bone mineral (DBBM) mixed with recombinant human bone morphogenetic protein-2 (rhBMP-2); DBBM/PDGF = DBBM mixed with recombinant platelet-derived growth factor (rhPDGF-BB). B=native bone; $\mathrm{NB}=$ new bone formation; $\mathrm{BS}=$ bone substitute material; $\mathrm{OB}=$ outside bone formation.

Figure 3. Histologic slide at 30x magnification after 8 weeks of healing (H\&E). DBBM/BMP-2 group cylinder (a), DBBM/PDGF group cylinder (b), DBBM group cylinder (c) and empty control cylinder (d). DBBM/BMP-2 = bovine-derived particulated bone mineral (DBBM) mixed with recombinant human bone morphogenetic protein-2 (rhBMP-2); DBBM/PDGF = DBBM mixed with recombinant platelet-derived growth factor (rhPDGF-BB). B=native bone; 
$\mathrm{NB}=$ new bone formation; $\mathrm{BS}=$ bone substitute material; $\mathrm{OB}=$ outside bone formation.

Figure 4. Box Plot representing histomorphometrical values of $A A(\%)$ at 2 and 8 weeks. 


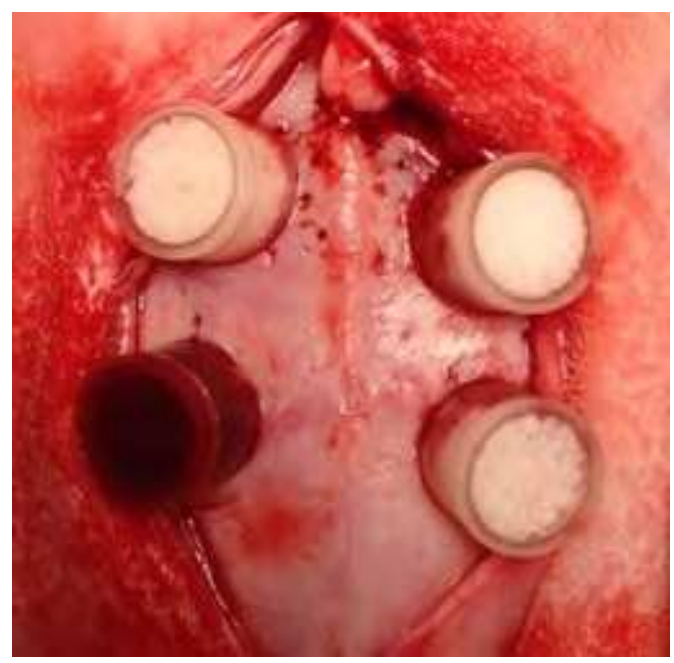

Figure 1a.

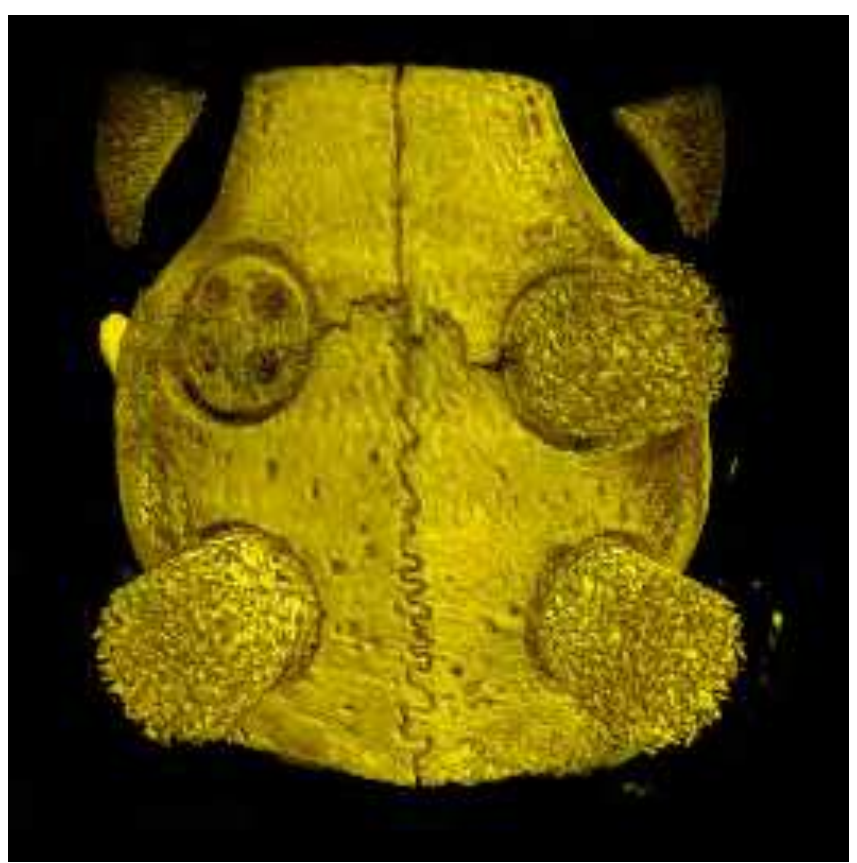

Figure $1 b$.

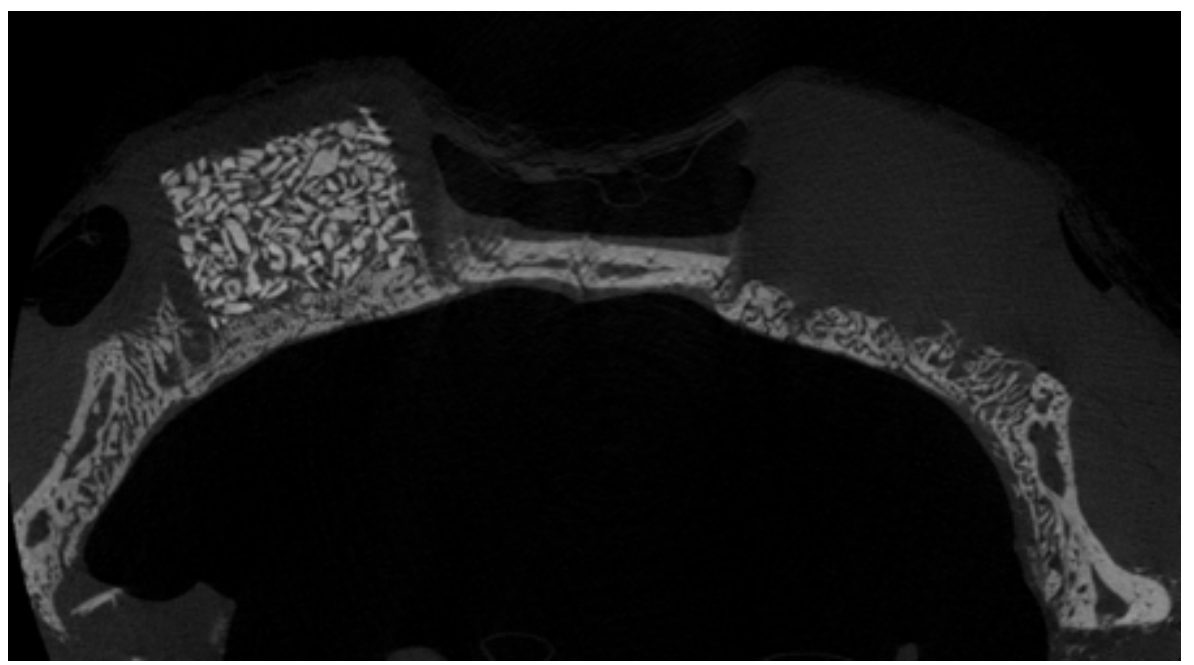

Figure 1c. 


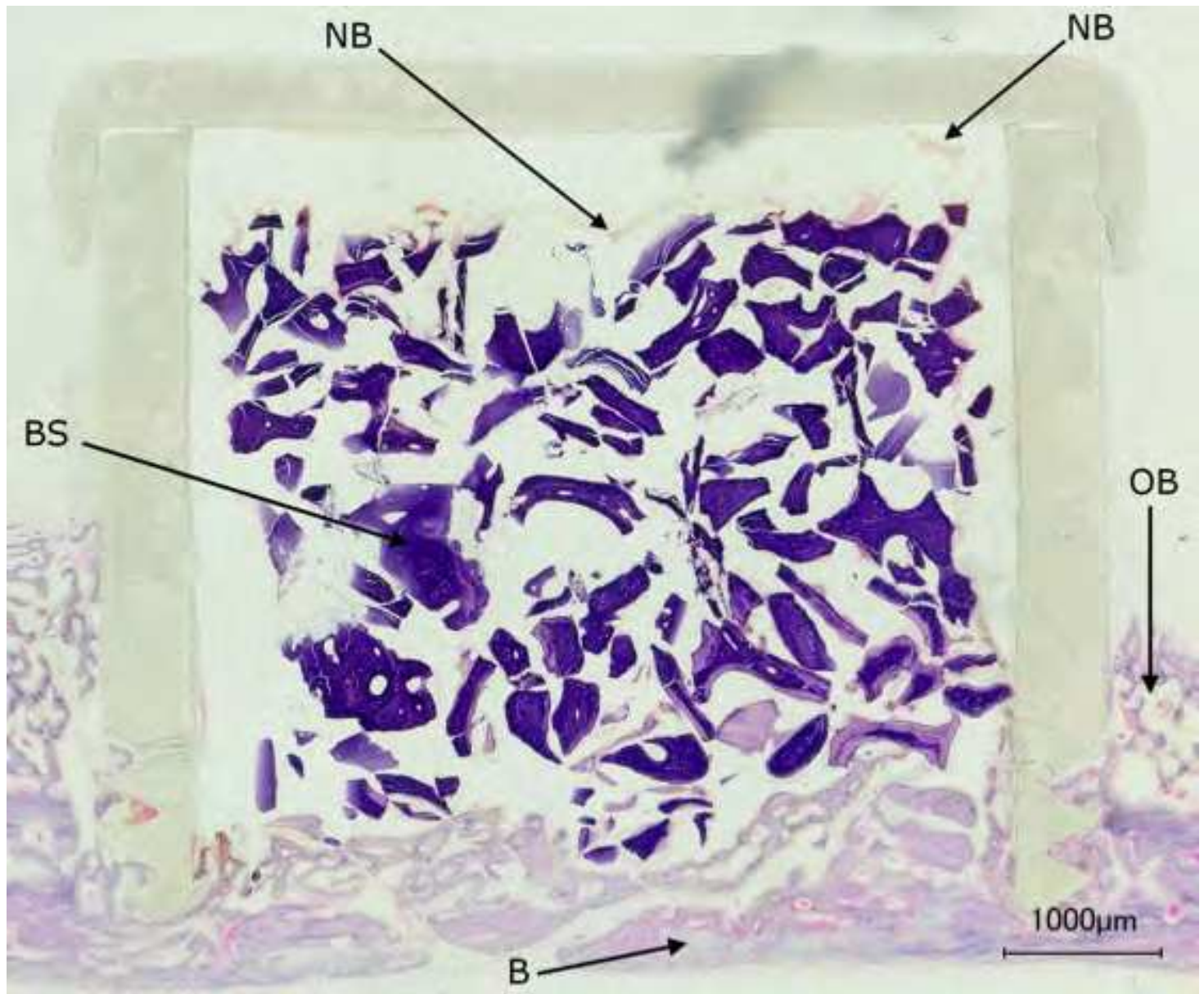

Figure 2a. 


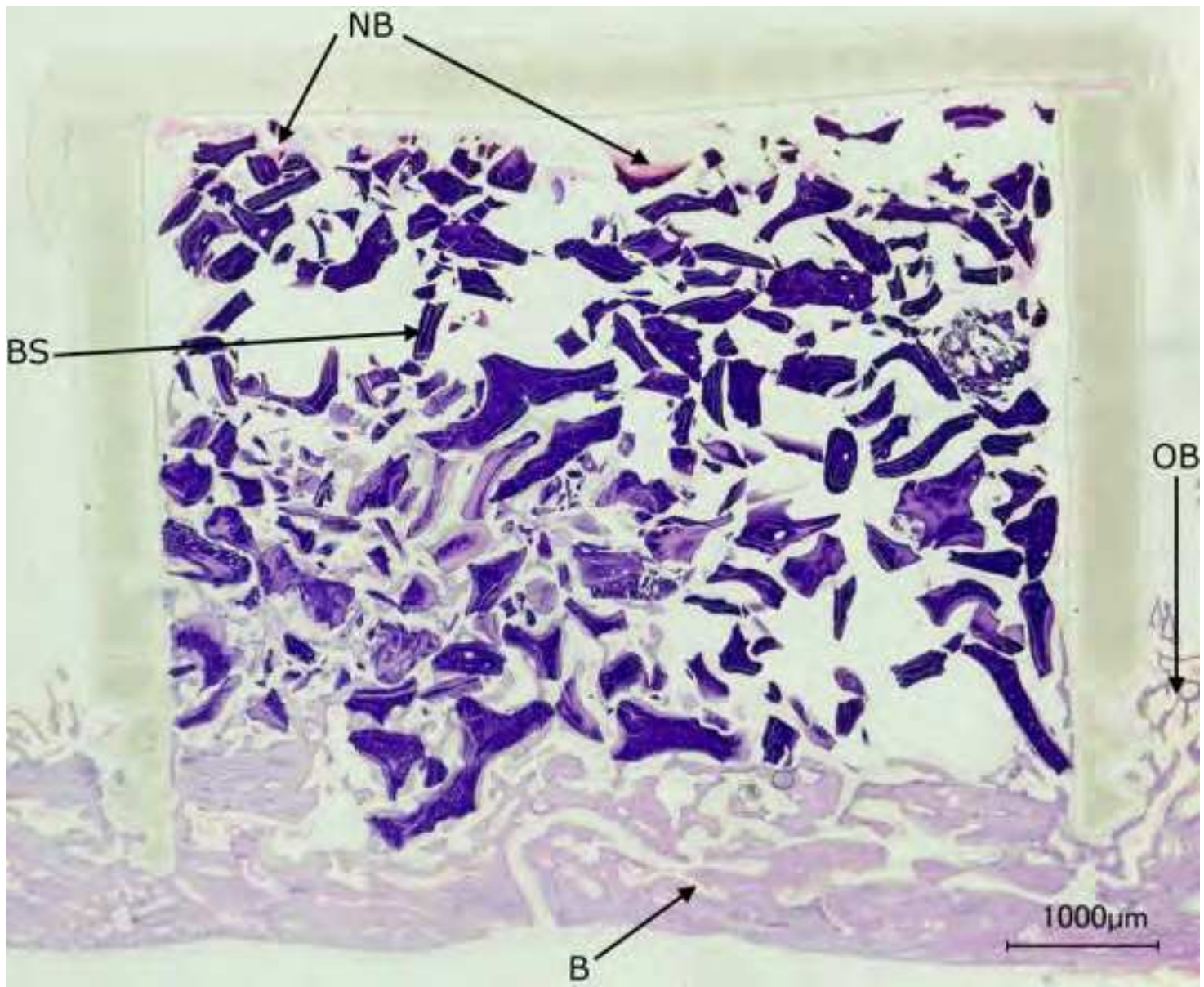

Figure $2 b$. 


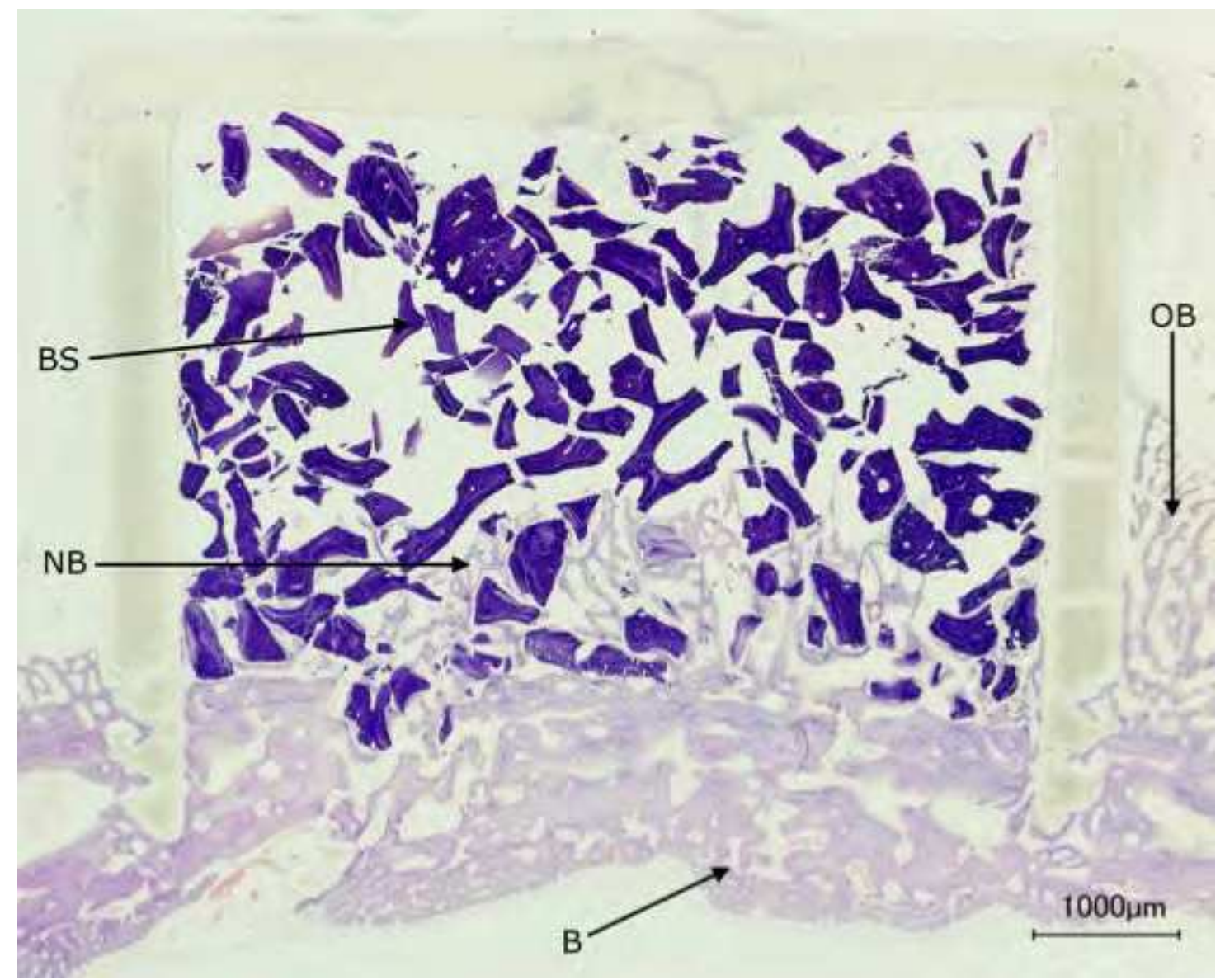

Figure 2c. 


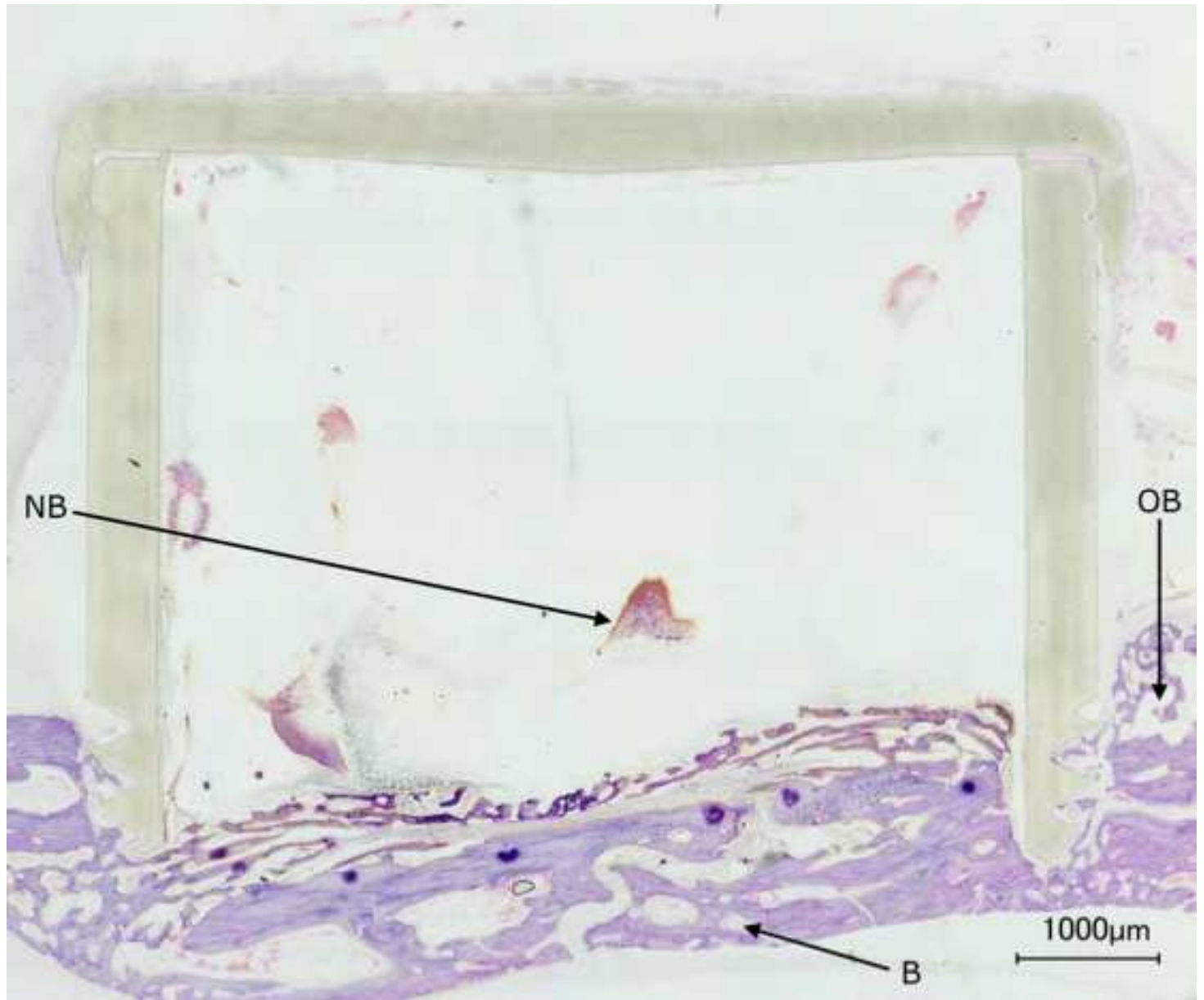

Figure $2 \mathrm{~d}$. 


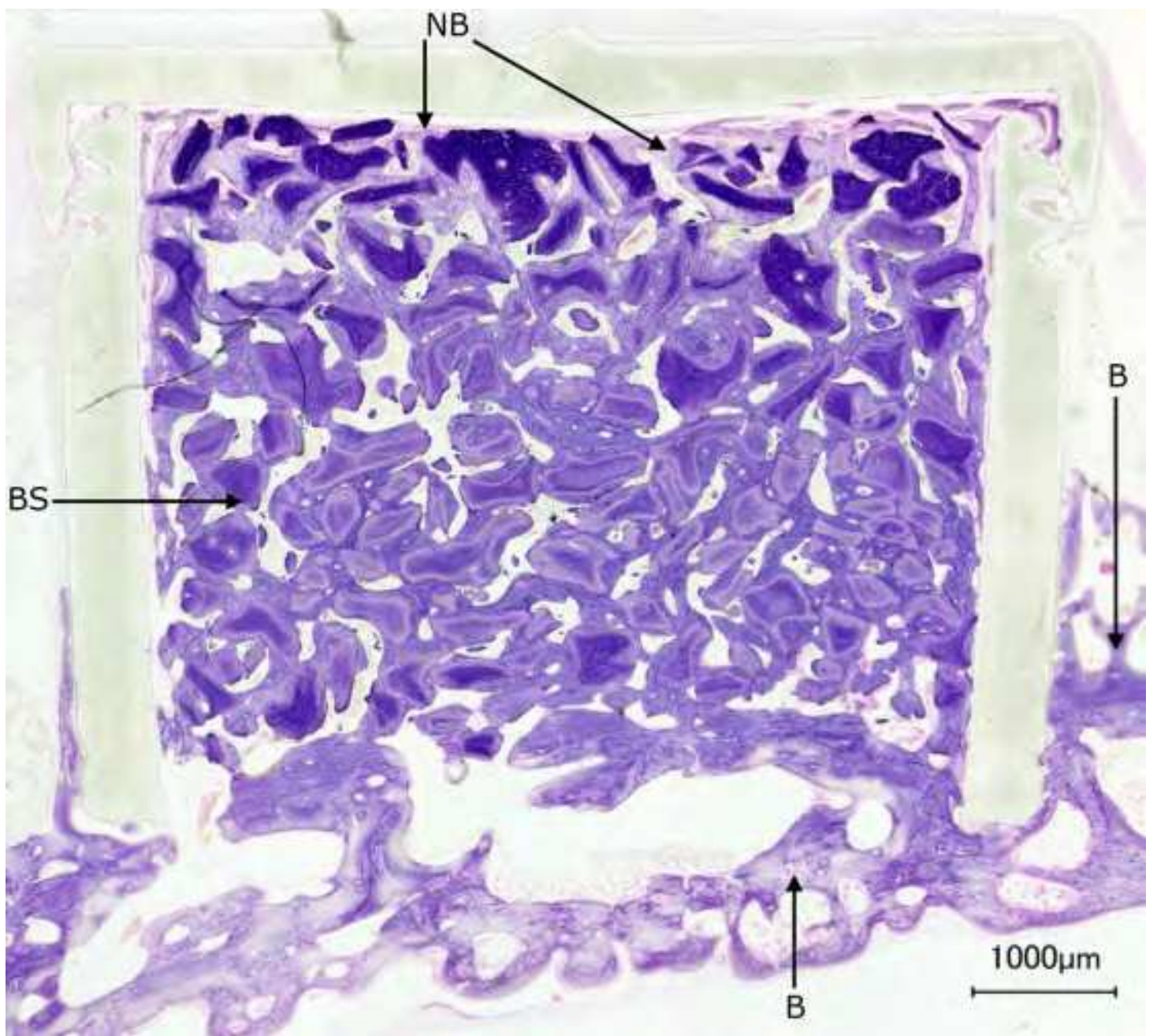

Figure $3 a$. 


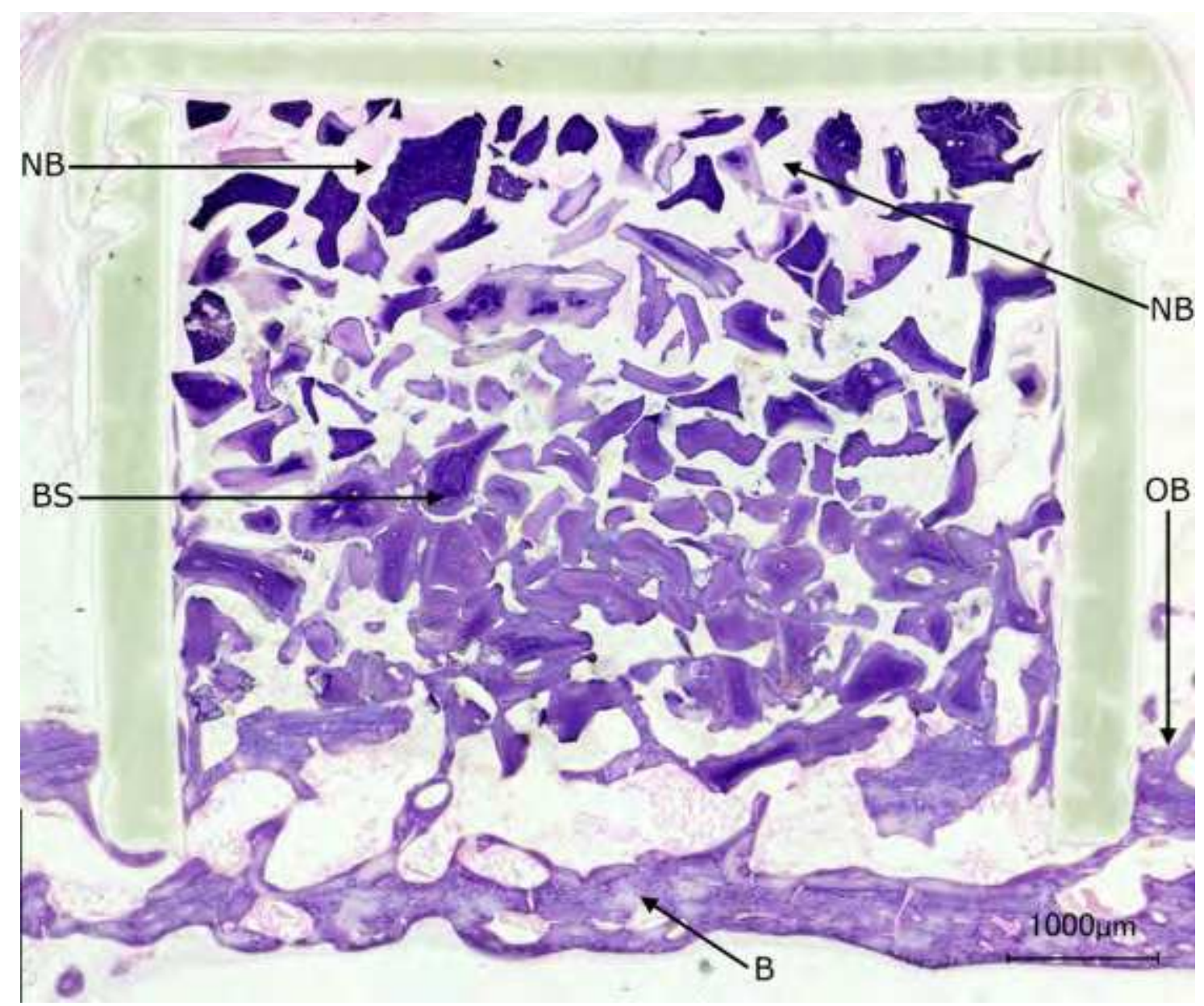

Figure 3b. 


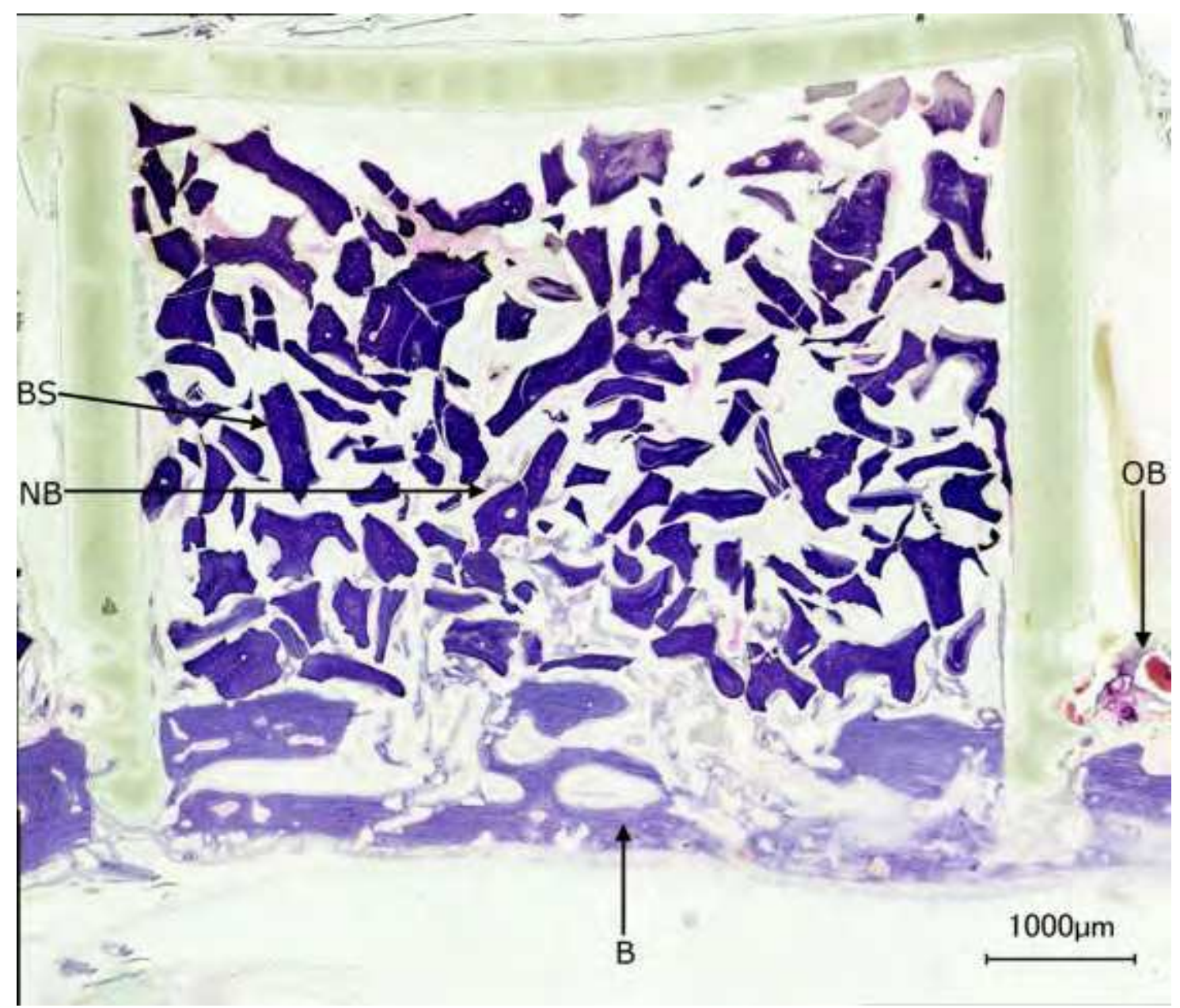

Figure 3c. 


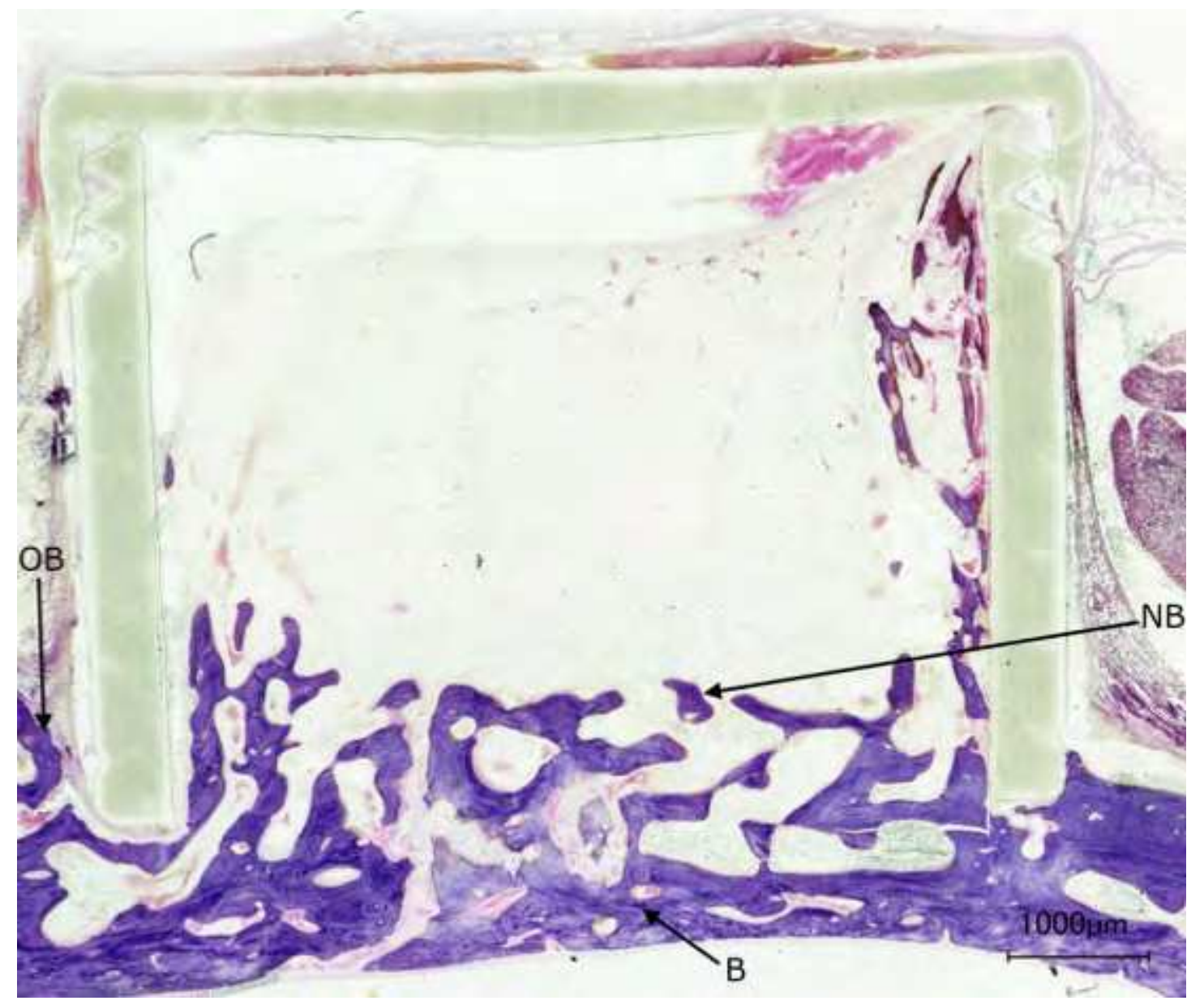

Figure $3 d$.

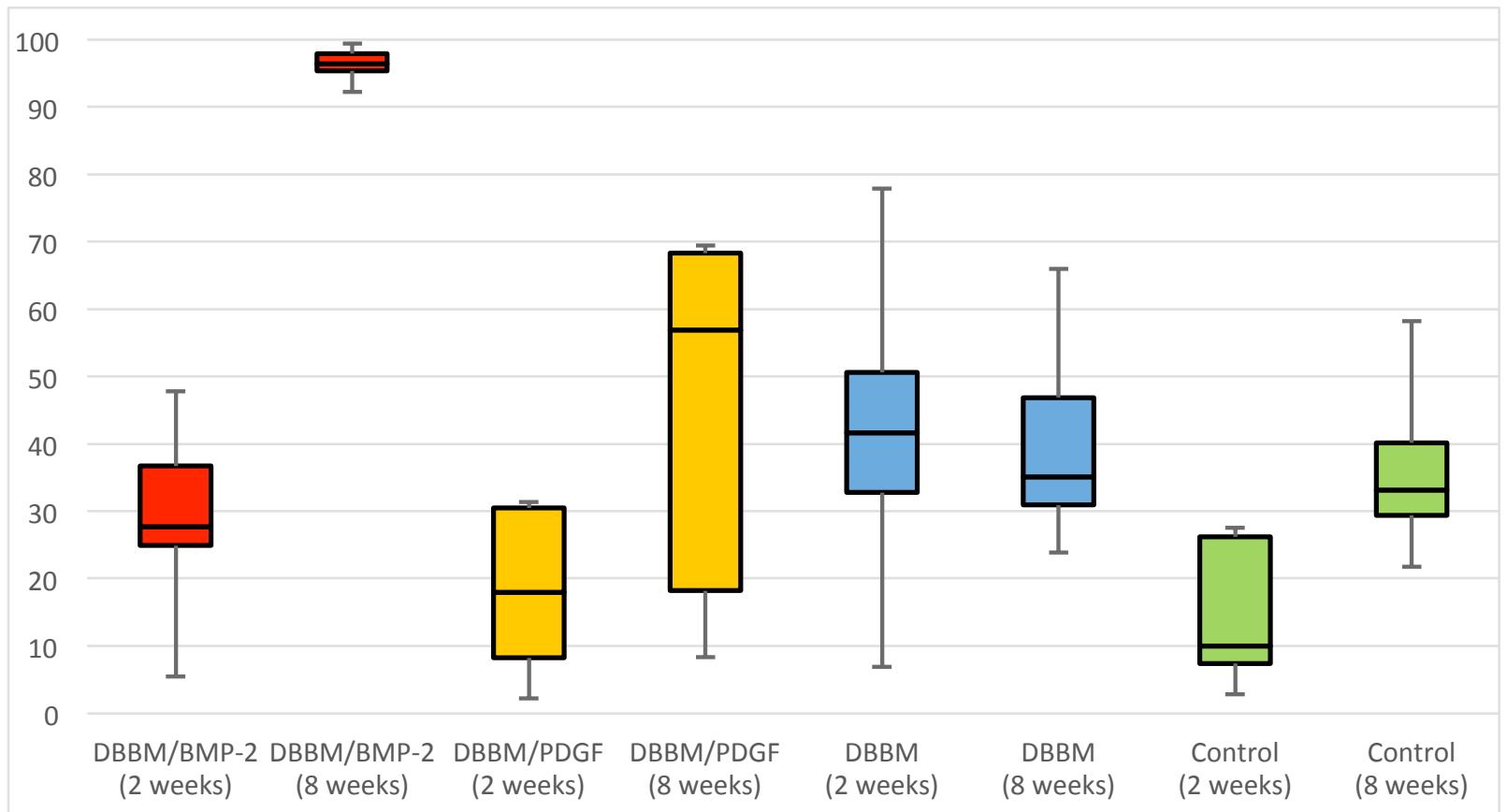

Figure 4. 
Table 1. Histomorphometrical analysis values (\%) at 2 and 8 weeks

\begin{tabular}{|c|c|c|c|c|c|c|c|c|c|}
\hline & & \multicolumn{2}{|c|}{ DBBM/BMP-2 } & \multicolumn{2}{|c|}{ DBBM/PDGF } & \multicolumn{2}{|c|}{ DBBM } & \multicolumn{2}{|c|}{ Control } \\
\hline & & $\begin{array}{l}\text { Mean } \\
\text { (SD) }\end{array}$ & $\begin{array}{l}\text { Median } \\
\text { [Q1; Q3] }\end{array}$ & $\begin{array}{l}\text { Mean } \\
\text { (SD) }\end{array}$ & $\begin{array}{l}\text { Median } \\
\text { [Q1; Q3] }\end{array}$ & $\begin{array}{l}\text { Mean } \\
\text { (SD) }\end{array}$ & $\begin{array}{l}\text { Median } \\
\text { [Q1; Q3] }\end{array}$ & $\begin{array}{l}\text { Mean } \\
\text { (SD) }\end{array}$ & $\begin{array}{l}\text { Median } \\
\text { [Q1; Q3] }\end{array}$ \\
\hline \multirow{8}{*}{$2 \mathrm{~W}$} & $\mathrm{AA}_{\text {Histo }}$ & $\begin{array}{c}28.40 \\
(14.07)\end{array}$ & $\begin{array}{c}27.73 \\
{[24.93 ; 36.71]}\end{array}$ & $\begin{array}{c}18.05 \\
(12.77)\end{array}$ & $\begin{array}{c}17.98 \\
{[8.27 ; 30.51]}\end{array}$ & $\begin{array}{c}41.91 \\
(23.38)\end{array}$ & $\begin{array}{c}41.65 \\
{[32.81 ; 50.62]}\end{array}$ & $\begin{array}{c}14.01 \\
(10.35)\end{array}$ & $\begin{array}{c}10.01 \\
{[7.41 ; 26.22]}\end{array}$ \\
\hline & B Histo & 7.76 & $\begin{array}{l}7.17 \\
46.10801\end{array}$ & 6.44 & 6.07 & 11.60 & 9.52 & 6.09 & 5.25 \\
\hline & & $(3.82)$ & {$[6.06 ; 10.80]$} & $(2.92)$ & {$[4.81 ; 9.21]$} & $(4.35)$ & {$[9.05 ; 15.42]$} & $(4.13)$ & [2.17; 9.18] \\
\hline & $\mathrm{BS}_{\text {Histo }}$ & 31.70 & 30.68 & 35.08 & 36.33 & 35.78 & 34.65 & 0 & 0 \\
\hline & DSHisto & $(3.55)$ & [29.56; 32.39] & $(7.18)$ & {$[30.55 ; 40.67]$} & (6.31) & [32.16; 42.45] & $(0)$ & {$[0 ; 0]$} \\
\hline & MTHisto & $39.46^{\mathrm{a}}$ & $39.77^{\mathrm{a}}$ & $41.52^{\mathrm{a}}$ & $43.86^{\mathrm{a}}$ & $47.38^{\mathrm{a}}$ & $45.89^{\mathrm{a}}$ & 6.09 & 5.25 \\
\hline & DIS MISO & (3.24) & {$[37.43 ; 41.55]$} & (6.62) & {$[39.76 ; 45.48]$} & (8.32) & {$[44.02 ; 51.27]$} & $(4.13)$ & {$[2.17 ; 9.18]$} \\
\hline & $\mathrm{NMT}_{\text {Histo }}$ & $\begin{array}{l}59.58^{\mathrm{a}} \\
(3.36)\end{array}$ & $\begin{array}{c}59.63^{\mathrm{a}} \\
{[57.29 ; 61.34]}\end{array}$ & $\begin{array}{l}57.55^{\mathrm{a}} \\
(6.71)\end{array}$ & $\begin{array}{c}55.62^{\mathrm{a}} \\
{[53.41 ; 58.78]}\end{array}$ & $\begin{array}{l}51.41^{\mathrm{a}} \\
(8.28)\end{array}$ & $\begin{array}{c}53.20^{\mathrm{a}} \\
{[47.65 ; 54.53]}\end{array}$ & $\begin{array}{l}93.47 \\
(4.26)\end{array}$ & $\begin{array}{c}94.37 \\
{[90.05 ; 97.51]}\end{array}$ \\
\hline \multirow{5}{*}{$8 \mathrm{~W}$} & AA $A_{\text {Histo }}$ & $\begin{array}{l}96.29^{\mathrm{abc}} \\
(2.44)\end{array}$ & $\begin{array}{c}96.41^{\mathrm{abc}} \\
{[95.33 ; 97.93]}\end{array}$ & $\begin{array}{l}46.37 \\
(26.45)\end{array}$ & $\begin{array}{c}56.91 \\
{[18.23 ; 68.33]}\end{array}$ & $\begin{array}{c}39.66 \\
(15.06)\end{array}$ & $\begin{array}{c}35.11 \\
{[30.96 ; 46.86]}\end{array}$ & $\begin{array}{c}35.98 \\
(12.48)\end{array}$ & $\begin{array}{c}33.16 \\
{[29.40 ; 40.16]}\end{array}$ \\
\hline & B Histo & $\begin{array}{c}35.62^{\mathrm{abc}} \\
(5.06)\end{array}$ & $\begin{array}{c}35.89^{\mathrm{abc}} \\
{[30.40 ; 40.33]}\end{array}$ & $\begin{array}{l}14.83 \\
(6.75)\end{array}$ & $\begin{array}{c}16.74 \\
{[7.47 ; 18.54]}\end{array}$ & $\begin{array}{l}11.62 \\
(2.28)\end{array}$ & $\begin{array}{c}12.67 \\
{[11.16 ; 12.94]}\end{array}$ & $\begin{array}{l}13.37 \\
(3.13)\end{array}$ & $\begin{array}{c}13.14 \\
{[10.62 ; 16.11]}\end{array}$ \\
\hline & BS Histo & $\begin{array}{l}32.46 \\
(7.97)\end{array}$ & $\begin{array}{c}35.12 \\
{[32.34 ; 35.23]}\end{array}$ & $\begin{array}{l}35.78 \\
(2.44)\end{array}$ & $\begin{array}{c}36.33 \\
{[33.10 ; 37.05]}\end{array}$ & $\begin{array}{l}33.97 \\
(3.22)\end{array}$ & $\begin{array}{c}33.95 \\
{[33.07 ; 35.99]}\end{array}$ & $\begin{array}{c}0 \\
(0)\end{array}$ & $\begin{array}{c}0 \\
{[0 ; 0]}\end{array}$ \\
\hline & $\mathrm{MT}_{\text {Histo }}$ & $\begin{array}{c}68.08^{\mathrm{abc}} \\
(6.36)\end{array}$ & $\begin{array}{c}68.63^{\mathrm{abc}} \\
{[65.53 ; 72.43]}\end{array}$ & $\begin{array}{l}50.61^{\mathrm{a}} \\
(6.92)\end{array}$ & $\begin{array}{c}53.96^{\mathrm{a}} \\
{[43.08 ; 55.80]}\end{array}$ & $\begin{array}{l}45.58^{a} \\
(3.71)\end{array}$ & $\begin{array}{c}46,00^{\mathrm{a}} \\
{[41.56 ; 47.15]}\end{array}$ & $\begin{array}{l}13.37 \\
(3.13)\end{array}$ & $\begin{array}{c}13.14 \\
{[10.62 ; 16.11]}\end{array}$ \\
\hline & $\mathrm{NMT}_{\text {Histo }}$ & $\begin{array}{c}29.60^{\mathrm{abc}} \\
(6.53)\end{array}$ & $\begin{array}{c}28.80^{\mathrm{abc}} \\
{[25.10 ; 32.14]}\end{array}$ & $\begin{array}{l}48.09^{a} \\
(7.30)\end{array}$ & $\begin{array}{c}44.73^{\mathrm{a}} \\
{[42.49 ; 56.25]}\end{array}$ & $\begin{array}{l}53.41^{\mathrm{a}} \\
(3.84)\end{array}$ & $\begin{array}{c}53.10^{\mathrm{a}} \\
{[51.86 ; 57.42]}\end{array}$ & $\begin{array}{l}86.02 \\
(3.19)\end{array}$ & $\begin{array}{c}86.25 \\
{[83.16 ; 88.95]}\end{array}$ \\
\hline
\end{tabular}

a: significantly different with control group $(p<0.001)$

$b$ : significantly different with DBBM group $(p<0.001)$

c: significantly different with DBBM/PDGF $(p<0.001)$

The area of bone regeneration $\left(\mathrm{AA}_{\mathrm{H} \text { isto }}\right)$; fraction of mineralized bone related to the total area $\left(\mathrm{B}_{\text {Histo }}\right)$; fraction of bone substitute related to the total area ( $\mathrm{BS}_{\text {Histo }}$ ); fraction of mineralized tissue related to the total area ( $\mathrm{MT}_{\text {Histo }}$ ); fraction of non-mineralized tissue related to the total area (NMTHisto). 
Table 2. Radiographic analysis (micro-CT) values (\%) at 2 weeks and 8 weeks

\begin{tabular}{|c|c|c|c|c|c|c|c|c|c|}
\hline & & \multicolumn{2}{|c|}{ DBBM/BMP-2 } & \multicolumn{2}{|c|}{ DBBM/PDGF } & \multicolumn{2}{|c|}{ DBBM } & \multicolumn{2}{|c|}{ Control } \\
\hline & & $\begin{array}{l}\text { Mean } \\
\text { (SD) }\end{array}$ & $\begin{array}{c}\text { Median } \\
{[Q 1 ; Q 3]}\end{array}$ & $\begin{array}{l}\text { Mean } \\
\text { (SD) }\end{array}$ & $\begin{array}{c}\text { Median } \\
\text { [Q1; Q3] }\end{array}$ & $\begin{array}{l}\text { Mean } \\
\text { (SD) }\end{array}$ & $\begin{array}{l}\text { Median } \\
\text { [Q1; Q3] }\end{array}$ & $\begin{array}{l}\text { Mean } \\
\text { (SD) }\end{array}$ & $\begin{array}{l}\text { Median } \\
{[Q 1 ; Q 3]}\end{array}$ \\
\hline \multirow{5}{*}{$2 W$} & $\mathrm{AA}_{\mathrm{m}-\mathrm{CT}}$ & $\begin{array}{l}43.87^{\mathrm{a}} \\
(5.53)\end{array}$ & $\begin{array}{c}43.06^{\mathrm{a}} \\
{[41.23 ; 46.89]}\end{array}$ & $\begin{array}{l}42.81^{a} \\
(6.46)\end{array}$ & $\begin{array}{c}43.15^{\mathrm{a}} \\
{[39.72 ; 47.06]}\end{array}$ & $\begin{array}{l}48.71^{a} \\
(8.07)\end{array}$ & $\begin{array}{c}47.26^{\mathrm{a}} \\
{[45.73 ; 50.35]}\end{array}$ & $\begin{array}{c}0.96 \\
(0.94)\end{array}$ & $\begin{array}{c}0.90 \\
{[0.20 ; 1.07]}\end{array}$ \\
\hline & $\mathrm{B}_{\mathrm{m}-\mathrm{CT}}$ & $\begin{array}{c}0.87 \\
(0.28)\end{array}$ & $\begin{array}{c}0.89 \\
{[0.69 ; 1.06]}\end{array}$ & $\begin{array}{c}1.05 \\
(0.58)\end{array}$ & $\begin{array}{c}0.85 \\
{[0.59 ; 1.59]}\end{array}$ & $\begin{array}{c}0.81 \\
(0.22)\end{array}$ & $\begin{array}{c}0.72 \\
{[0.65 ; 0.91]}\end{array}$ & $\begin{array}{c}0.61 \\
(0.52)\end{array}$ & $\begin{array}{c}0.65 \\
{[0.15 ; 0.71]}\end{array}$ \\
\hline & $\mathrm{BS}_{\mathrm{m}-\mathrm{CT}}$ & $\begin{array}{l}29.05 \\
(4.50)\end{array}$ & $\begin{array}{c}29.37 \\
{[27.11 ; 33.04]}\end{array}$ & $\begin{array}{l}27.06 \\
(5.33)\end{array}$ & $\begin{array}{c}26.03 \\
{[25.89 ; 28.93]}\end{array}$ & $\begin{array}{l}32.64 \\
(5.90)\end{array}$ & $\begin{array}{c}32.57 \\
{[28.62 ; 33.57]}\end{array}$ & $\begin{array}{c}0 \\
(0)\end{array}$ & $\begin{array}{c}0 \\
{[0 ; 0]}\end{array}$ \\
\hline & $\mathrm{MT}_{\mathrm{m}-\mathrm{CT}}$ & $\begin{array}{l}40.47^{a} \\
(4.62)\end{array}$ & $\begin{array}{c}41.31^{\mathrm{a}} \\
{[36.95 ; 42.68]}\end{array}$ & $\begin{array}{l}38.16^{a} \\
(4.81)\end{array}$ & $\begin{array}{c}38.03^{\mathrm{a}} \\
{[35.82 ; 42.08]}\end{array}$ & $\begin{array}{l}45.15^{a} \\
(5.46)\end{array}$ & $\begin{array}{c}44.81^{\mathrm{a}} \\
{[42.34 ; 48.04]}\end{array}$ & $\begin{array}{c}0.84 \\
(0.74)\end{array}$ & $\begin{array}{c}0.86 \\
{[0.22 ; 1.02]}\end{array}$ \\
\hline & $\mathrm{NMT}_{\mathrm{m}-\mathrm{CT}}$ & $\begin{array}{l}13.94^{a} \\
(2.24)\end{array}$ & $\begin{array}{c}13.39^{\mathrm{a}} \\
{[13.06 ; 14.72]}\end{array}$ & $\begin{array}{l}14.69^{a} \\
(2.52)\end{array}$ & $\begin{array}{c}13.92^{\mathrm{a}} \\
{[13.15 ; 15.77]}\end{array}$ & $\begin{array}{l}15.26^{a} \\
(2.46)\end{array}$ & $\begin{array}{c}15.15^{\mathrm{a}} \\
{[13.40 ; 16.09]}\end{array}$ & $\begin{array}{c}0.98 \\
(1.42)\end{array}$ & $\begin{array}{c}0.37 \\
{[0.12 ; 1.17]}\end{array}$ \\
\hline \multirow{5}{*}{$8 W$} & $\mathrm{AA}_{\mathrm{m}-\mathrm{CT}}$ & $\begin{array}{c}63.65^{\mathrm{abc}} \\
(6.10)\end{array}$ & $\begin{array}{c}63.77^{\mathrm{abc}} \\
{[58.21 ; 67.95]}\end{array}$ & $\begin{array}{l}50.21^{\mathrm{a}} \\
(4.34)\end{array}$ & $\begin{array}{c}51.85^{\mathrm{a}} \\
{[45.50 ; 52.25]}\end{array}$ & $\begin{array}{l}44.81^{a} \\
(3.75)\end{array}$ & $\begin{array}{c}44.09^{\mathrm{a}} \\
{[42.82 ; 47.01]}\end{array}$ & $\begin{array}{c}4.57 \\
(1.88)\end{array}$ & $\begin{array}{c}4.18 \\
{[3.64 ; 5.32]}\end{array}$ \\
\hline & $\mathrm{B}_{\mathrm{m}-\mathrm{CT}}$ & $\begin{array}{c}0.87^{a} \\
(0.27)\end{array}$ & $\begin{array}{c}0.87^{\mathrm{a}} \\
{[0.63 ; 0.96]}\end{array}$ & $\begin{array}{l}0.90^{\mathrm{a}} \\
(0.25)\end{array}$ & $\begin{array}{c}0.84^{\mathrm{a}} \\
{[0.70 ; 1.04]}\end{array}$ & $\begin{array}{l}1.20^{a} \\
(0.31)\end{array}$ & $\begin{array}{c}1.29^{\mathrm{a}} \\
{[0.95 ; 1.44]}\end{array}$ & $\begin{array}{c}2.65 \\
(1.18)\end{array}$ & $\begin{array}{c}2.28 \\
{[1.84 ; 3.37]}\end{array}$ \\
\hline & $\mathrm{BS}_{\mathrm{m}-\mathrm{CT}}$ & $\begin{array}{c}49.07^{b c} \\
(6.55)\end{array}$ & $\begin{array}{c}49.51^{\mathrm{bc}} \\
{[42.83 ; 53.85]}\end{array}$ & $\begin{array}{l}36.41 \\
(3.12)\end{array}$ & $\begin{array}{c}37,00 \\
{[32.97 ; 38.13]}\end{array}$ & $\begin{array}{l}32.04 \\
(3.26)\end{array}$ & $\begin{array}{c}32.12 \\
{[29.31 ; 35.06]}\end{array}$ & $\begin{array}{c}0 \\
(0)\end{array}$ & $\begin{array}{c}0 \\
{[0 ; 0]}\end{array}$ \\
\hline & $\mathrm{MT}_{\mathrm{m}-\mathrm{CT}}$ & $\begin{array}{c}76.52^{a b c} \\
(8.18)\end{array}$ & $\begin{array}{c}77.96^{\mathrm{abc}} \\
{[74.98 ; 81.95]}\end{array}$ & $\begin{array}{l}48.30^{a} \\
(14.04)\end{array}$ & $\begin{array}{c}50.52^{\mathrm{a}} \\
{[46.75 ; 57.66]}\end{array}$ & $\begin{array}{l}50.13^{a} \\
(5.92)\end{array}$ & $\begin{array}{c}49.59^{\mathrm{a}} \\
{[45.14 ; 53.84]}\end{array}$ & $\begin{array}{c}4.02 \\
(1.75)\end{array}$ & $\begin{array}{c}3.54 \\
{[2.86 ; 5.31]}\end{array}$ \\
\hline & $\mathrm{NMT}_{\mathrm{m}-\mathrm{CT}}$ & $\begin{array}{c}13.71^{a b} \\
(0.40)\end{array}$ & $\begin{array}{c}13.67^{\mathrm{ab}} \\
{[13.53 ; 14.05]}\end{array}$ & $\begin{array}{l}12.90^{\mathrm{a}} \\
(1.50)\end{array}$ & $\begin{array}{c}13.28^{\mathrm{a}} \\
{[11.56 ; 14.12]}\end{array}$ & $\begin{array}{l}11.58^{a} \\
(1.47)\end{array}$ & $\begin{array}{c}11.83^{\mathrm{a}} \\
{[10.71 ; 12.20]}\end{array}$ & $\begin{array}{c}1.92 \\
(0.81)\end{array}$ & $\begin{array}{c}1.81 \\
{[1.52 ; 2.42]}\end{array}$ \\
\hline
\end{tabular}

a: significantly different with control group $(p<0.001)$

$b$ : significantly different with DBBM group $(p<0.001)$

c: significantly different with DBBM/PDGF $(p<0.001)$

The area of bone regeneration $\left(A A_{m-C T}\right)$; fraction of mineralized bone related to the total area $\left(B_{m}-C T\right)$; fraction of bone substitute related to the total area

$\left(B S_{m-C T}\right)$; fraction of mineralized tissue related to the total area (MT $\left.\mathrm{m}-\mathrm{CT}\right)$; fraction of non-mineralized tissue related to the total area (NMT $\left.\mathrm{m}-\mathrm{CT}\right)$. 